The Brock Review Volume 12 No. 2 (2012)

(C) Brock University

\title{
A Million Miles From Broadway
}

\author{
Mel Atkey
}

\begin{abstract}
Musical theatre can take root anywhere. The future of the musical may very well lie beyond Broadway and the West End. In recent years, successful musicals have been developed in Canada, Australia and the German speaking countries. Some, like Elisabeth, have travelled internationally without ever playing in English. Companies in Korea, Japan and China are investing in new works, both domestically and internationally. These different countries can learn from each other. In South Africa, people do literally burst into song on the streets. During the apartheid era, some of the freedom fighters were known to have gone to the gallows singing. Both there and in Argentina, musical theatre played an active role in the struggle against oppression. Shows like Sarafina weren't just about the struggle against apartheid, they were part of it. This is nothing new the cabarets of Weimar Berlin were also struggling against oppression. In fact, the birth of the musical coincided with the birth of democracy. On the other hand, during World War II, the allfemale Takarazuka Revue was co-opted by the Japanese government for propaganda purposes.
\end{abstract}

The real point of my book A Million Miles from Broadway is not just to tell a history of the musical. It's what you do with that history after you've learned it that is important. Firstly to learn about our own musical theatre heritage, but also to learn about each other's. We may find that people in other countries have found solutions to problems that we are struggling with.

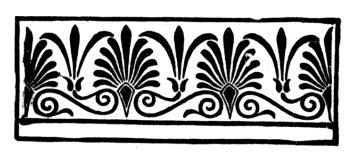

It may come as a surprise to the people reading this issue that no musical theatre exists outside of New York City. ${ }^{1}$ At least, that was the assertion made a couple of decades back by the late Peter Stone, a Tony award-winning librettist and former president of the Dramatists Guild. Since I write musicals and am not a New Yorker, that statement put a bee in my bonnet, and that bee has never escaped. (I know, because I have been stung numerous times.) 
A little while ago I was talking to an American in London who was about to teach a master class for librettists. A veteran of the Lehman Engel workshops, he was lamenting the lack of craftsmanship in British musicals, saying that great playwrights do not necessarily make great book writers. This I agreed with, but then he said that because the musical was an American form, only American writers understood certain things, such as that the central character in a musical has to be proactive, not passive. I began to wonder about this. I have always stressed the need for craft and for a firm knowledge of the work that has gone before us, but I questioned whether he was confusing universal principles of drama with more culturally specific conventions. America is more of a maverick, individualistic society than Britain is. Some of the brassier American musicals such as Guys and Dolls and A Chorus Line have never achieved the same success in Britain as they did at home. The English tend to bristle at any in-your-face aggression. On the other hand, Fiddler on the Roof enjoyed a long run in London, but it features a central character who is passive; i.e. things happen to him and around him, without him making them happen.

I envisage musical theatre as an international art form, just as cinema is. In order for that to happen, it has to be liberated from the idea that it is the exclusive property of one nation or ethnic group. When I talk about "universality" in the musical theatre, I bear in mind that nothing is entirely universal. Everything works slightly differently in each place you do it. When a Japanese producer asked Joseph Stein how American audiences could understand Fiddler on the Roof when it was "so Japanese,"2 he had a good point: what do Americans know of arranged marriages?

It is possible, I believe, to have a paradigm so firmly fixed in our minds that we reject anything that does not conform to it. I say this because the "craft" argument seems to hit a snag when shows such as Spring Awakening that defy these "rules," appear to be outperforming their more conventional rivals. I'm not defending these shows, but they do seem to satisfy a demand that the "well-made" shows do not. Is there a median to be found between preserving and developing the craft on the one hand, and allowing the musical to be tailored to other cultures and circumstances? It would require teachers and artists with a firm grounding in the disciplines of musical theatre who also have a profound respect for other cultures and forms. For example, at London's Theatre Royal Stratford East, they have a commitment to nurture so-called Urban Musicals that make use of rap and hip-hop, among other forms, and for a time they managed to bring over teachers from the Tisch School to work with their young writers.

My aim is not to detract, in any way, from the colossal achievements of Broadway. My aim is to learn from them, but to always bear in mind that we are not like them. It is indisputable that, for 
the second half of the twentieth century, the Americans were the masters. However, that doesn't necessarily mean that New York is the musical's end destination. The American musical is a branch of the tree-albeit the most successful one-but it is not the root. Alan Jay Lerner, the librettist behind My Fair Lady said, "Broadway cannot live without the musical theatre, but the musical theatre can live without Broadway. After all, its first home was Paris and then Vienna and then London and then New York. So changes of address are not uncommon." In spite of claims that the "golden age" of the musical is over, I think we should remain open to the possibility that the best is yet to come.

I'm not looking for a fait-accomplis. I'm looking for seeds that can be watered. As a nonAmerican, I've always found the assertion that one nation held the lock and keys to the form to be at best intimidating, and at worst, stifling. After all, it is not just the Italians who write opera.

In fact, difficult though it may be to believe, Americans have had their own inferiority complex to contend with: the fear that they may be Rome to Britain's Greece. This has made them into vociferous defenders of what they believe to be "their" art form-and all power to them. If others want to make it their own, they will have to find their own way, just as the Americans did. It was early in the twentieth century, when the American musical was in its infancy, that people like Jerome Kern looked for ways to make what was then still a very European form into a distinctly American one. In her biography of Leonard Bernstein, Meryle Secrest writes, "The role of American composers in building a brave new world was to create a uniquely American contribution, based on the New England heritage of hymns, dances and folk songs and on the rich and exploitable vein of Negro rhythmic patterns and tone colors." ${ }^{\prime 4}$ New Hampshire based composer and educator John Warthen Struble writes, "The imagination of America was turned inward during the Depression, toward things American, and foreign musical influences held less power than at any previous time in our history." 5 . In other words, they were playing to the home audience.

Others would be wise to learn that same lesson. Lionel Bart did. British musicals had difficulty travelling abroad until Bart found that, with Oliver!, he could combine the Broadway principles of integrated story-telling with English music hall forms. Just as American popular song had adopted-and in some cases invented-a slang vernacular, Bart's East Enders were heard as they actually spoke. "It's hard now to realise how thoroughly he transformed the British musical," wrote Michael Coveney in London's The Independent. "He mined an entire semi-submerged territory of music hall, parlour songs and cockney anthems and filtered them through an idiosyncratic gift for rhythm, phrase-making and song construction." ${ }^{\prime 6}$ Before Bart, British musicals were for the most 
part twee and slight. Even Ivor Novello's shows never worked Stateside. Their continental counterparts had a better excuse. They were murdered in cold blood.

However, let us consider the implications of any potential "change of address." Up until the late 1940s, the American popular music industry was based in New York's Tin Pan Alley. They supplied the songs not only for the music charts but for Broadway and Hollywood as well, and over a period of fifty years or so, had evolved a high level of craftsmanship and sophistication. Then a combination of technological change, economics and the baby boom brought an end to New York's hegemony. Songwriters from outside of New York (and Hollywood) had a look-in for the first time. Sadly, the tidal wave that was the rock and roll generation swept away much that came before it, including the craftsmanship.

At its peak, the American musical educated its audience, advancing a more sophisticated art form without forsaking its populist roots. Leonard Bernstein did this. So did Kurt Weill. For that matter, so did Mozart. Now, we're more polarised between the relative "high brow" of Sondheim and the "low brow" of juke-box musicals, and we've lost some of the middle ground. We're not appealing to the popular audience where they are, then raising them to something higher.

One of the things that I have discovered in my historical research is that the birth of modern musical theatre coincided with the birth of democracy. Mozart wrote The Magic Flute with a mass audience in mind, not the elite. Offenbach began to prosper when France's theatres were deregulated. Just as the American Revolution can be seen in a broader context as an extension of the English Civil War, the development of the American musical comedy was a continuation of a process that had begun in Europe.

Keeping this in mind, it makes sense to me that the form should be localised, and speak to the audience at hand. After all, it is through attention to the specific that we become universal. The Irish playwright John Coulter, who immigrated to Canada in 1936 said, "What virtue is there in becoming specifically Canadian? Why not aim at the idea of internationalism in the theatre at least? I should reply that in my belief the way to internationalism in the theatre as in all else lies through the prior achievement of the greatest degree of nationalism. It is an organic growth outward from a core which is the individual himself, in this case, the individual playwright.",7

Film is an example of internationalised form that, although dominated by Hollywood, retains an alternative "World Cinema" view. The French "New Wave" directors, including François Truffaut and Jean-Luc Goddard, idolised the Hollywood films of Hitchcock and others, yet they created a form of their own, as did Fellini and Bergman. I would like to see a "World Musical 
Theatre" movement develop. The lesson, I believe, is to try to find ways of combining the craft of Broadway with the indigenous local forms.

I have spent the past few years on a quest to discover some of those musicals that Mr. Stone thinks don't exist in other countries. I began, of course, in my own back yard here in Canada. Inspired by Mavor Moore and Norman Campbell, I sought out what I believed were indigenous roots in my own country, tracing from the first pastiche operettas-HMS Parliament, Ptarmiganthrough Spring Thaw and the beginnings of the Charlottetown Festival. I also looked at the collective creations of the alternate theatre movement, such as Paper Wheat and Ten Lost Years. The result of that research was a book called Broadway North-The Dream of a Canadian Musical Theatre.

I was pleasantly surprised by its reception outside of Canada. In fact, several Australians told me that, if you changed the names, it could be their story. Both countries are former British colonies with a small population spread over a huge, largely uninhabitable expanse. Both embraced a policy of official multiculturalism. Where we have the inferiority complex, they have the "cultural cringe." Both developed traditions of collective, alternate theatre, and Sydney's Phillip Street Revue, which gave us Dame Edna Everage, occupies a similar place in their history to Spring Thaw, which gave us Charlie Farquarson. (In fact, Rowan and Martin's Laugh-in was largely created and written by veterans of both).

I emerged from my research with a basic principle. We study the craftsmanship of the great works, but we also study our own environment, and the works that have emerged in our own back yard. That way, we learn to address our own audience and to recognise our own voice. In order to do so, we also study how other people in other environments have adapted.

The arguments about the origin of the musical are heavily reliant on the semantics of the term. Is a musical a different species than an operetta? Does $A$ Little Night Music somehow have more in common with No No Nanette than with The Merry Widow? In Europe, musical theatre was treated as an off-shoot of opera, even when some of the so-called operettas veered a great deal in style from the operatic form. For instance, in many cases Gilbert and Sullivan employed comic actors who could carry a tune, rather than operatic voices. The Viennese "operettas" of Ralph Benatzky were hardly operatic at all. Just as Broadway was influenced by vaudeville and burlesque, European shows were affected by cabaret and music hall. Stephen Sondheim maintains that, if it is in a theatre, it is a musical; if it is in an opera house, it is an opera. But in Paris in the nineteenth century, it was less clear-cut. The Opéra-Comique, where Carmen was first played, catered to a more middlebrow audience than the more elitist Opéra Garnier. It was only when Carmen's spoken 
dialogue was replaced by recitative (after Bizet's death) that it was deemed acceptable as a "grand opera."

But most histories of the musical talk about European operetta only up to the point where it gave birth to the American musical. In truth the Americans and Europeans continued to crossfertilise each other for at least half a century-right up until a fellow named Adolph brought the whole European enterprise to a premature conclusion. (After the war, the Viennese were so determined to put their past behind them that they demolished most of their celebrated operetta houses). While Show Boat is rightly feted as the show that nudged the American musical in a more serious direction, nobody talks about Carmen in those terms because it is, of course, an opera and not a musical-even though, in its original version as conceived by Bizet, it had spoken dialogue, interrupted by songs in a form that was so close to that of Oklahoma that Oscar Hammerstein found it easily adaptable to the Broadway stage. It is purely speculative to suggest that had it not been for Hitler, Kurt Weill and Max Reinhardt may have continued their theatrical revolutions in Europe and the world may have been a very different place. We will never know.

However, my mission is not, strictly speaking, to be a historian. I want to water that neglected garden, and see what grows. As a composer and lyricist myself, it is the future that interests me. I study the works of the past in order to learn from both their triumphs and mistakes, and to maintain some sense of continuity. I am looking for foundations that can be built on-even if it hasn't happened yet. For instance, Ireland has yet to create a world-class musical, even though it is noted for its great drama, poetry, music and dance. But it could happen, and there are traditions that could be built on. This is far from reactionary-only by studying history do you learn how not to repeat it. Only by aquatinting ourselves with the work that has gone before do we find out what hasn't been tried.

Nor am I expounding my own theories of dramaturgy. I leave that to others. I merely want to point people in a certain direction, and trust that they will make their own discoveries. I want to show that the musical theatre form can be adapted to different cultural environments, but I am not going to dictate-or limit-how these adaptations will occur.

Some will question, why follow any other examples besides the successful Broadway ones? Because we are not in New York, and even if we were, anything we create is going to have an outsider's perspective. When Japanese director Amon Miyamoto staged The Drowsy Chaperone in Tokyo, he said, "I love this Canadian focus. This is how they loved musicals long distance... This is a Canadian viewpoint. That's what made me very excited when I saw it on Broadway... Japanese 
people looking at Broadway and Canadian people looking at Broadway, the distance is similar." If we simply try to imitate the American form, it will easily be detected as bogus.

It is important to understand what it is that is influencing you. Then you can decide whether to accept or reject it. As a western Canadian Anglo-Saxon Protestant, it would probably be silly for me to write a show that uses Klesmer music just because I'd seen Fiddler on the Roof a few dozen times, and think that is what a Broadway musical is supposed to sound like.

The normal course of study, as laid down by Lehman Engel and others, would be the works of the Broadway greats. I have prescribed something a little broader. For me, anybody in Canada who wants to learn how to create work that is distinctly Canadian will want to study the Canadian shows that went before them-Anne of Green Gables, Billy Bishop Goes to War. They may also want to consider how people in Australia write shows that are distinctly Australian. Or South African. Or Argentinean. Not in place of the "greats," but in addition to them.

Can the discipline and craft of the Broadway musical be exported? John Sparks, a pupil of Lehman Engel and the artistic director of the Academy of New Musical Theatre in Los Angeles, thinks it can. "I think that the Lehman Engel style workshop could work in any cultural setting, because it emphasises how the craft of the writing affects the communication in the theatre," he explains.

In other words, whatever one is trying to communicate, at whatever level of theatrical abstraction, a writer must remember that the words and music are a means to an end - therefore, the music and lyrics must work together in a way that clearly communicates to the audience at which the piece is aimed... How any particular audience hears and simultaneously understands songs in the context of their culture is certainly a factor in shaping the craft of song writing for that culture... In the theatre, regardless of cultural differences, one thing remains the same - it is not like listening to music in other forms because there are competing elements. Sets, costumes, movement, aspects of character, linguistic anomalies... the song in the theatre must cut through all the competition and communicate directly to the audience with no need to process the information. The audience must be able to understand it without thinking about it. ${ }^{8}$

In Australia, writers have tried to find ways of infusing their work with their irreverent, selfdeprecating "larrikin" humour. In Canada, Gratien Gélinas conceived the notion, which Spring Thaw developed, of "putting the audience on stage." In Singapore, writers are struggling to incorporate their distinctive Singlish dialect into musicals. In South Africa, they burst into song at the drop of a hat in real life. The tango was introduced to the world on the musical stages of Buenos Aires. All of these are lessons in how countries can make the musical their own. 
Let's begin by looking at one of the countries whose contribution to the musical theatre is generally acknowledged, if sometimes belittled. We like to talk of Paris as the place where musicals go to die, when in fact it should be celebrated as the form's birthplace. It was at the Théâtre des Bouffes-Parisiennes that Jacques Offenbach first had audiences dancing the can-can in the aisles with Orpheus in the Underworld in 1858. This was the beginning of the democratisation of opera, and we haven't looked back since. Musicals were being written for the commoners, not the elite. According to musicologist Wilfred Mellers, “Musical comedy-a Plain Man's popular art-had its origins in the impact of democracy on opera, which had been initially an aristocratic art." ${ }^{9}$ However, little work has travelled successfully in either direction between Paris and the other theatre centres since then, with two notable exceptions. The best known is Les Misérables, but I'm going to talk about the other one.

Irma la Douce succeeded in the English-speaking world, not because it was the first decent French musical since Tales of Hoffman (it wasn't, there have been others), but because somehow the people who adapted it got it right. To begin with, they trusted their material. Unlike most of the other attempts to "anglicise" French musicals, they didn't try to tone down its sauciness. Nor did they interpolate the works of other composers into it. After all, as the composer of the lion's share of Edith Piafs hits, Marguerite Monnot knew how to write a good tune. What they did do was search for a way to make librettist Alexandre Breffort's argot slang work for an English speaking audience. Rather than having the characters speak in, say, a cockney dialect, the adapters-Monty Norman, Julian More and David Henneker-introduced actual argot words into the dialogue, allowing their context to explain the meaning. For example, "grisbi" was slang for money, and "mec" for pimp. Thus, the love story of a prostitute and her "mec" was given at least the illusion of being in its proper "milieu."

Irma la Douce built not so much on the operetta tradition as that of cabaret and chanson, some of which is also evident in Les Misérables. Sadly, it was a bit of a last gasp for the French. It didn't help that, after the war, some of the once distinguished writers of Parisian musical comedy were accused of being collaborators (and I don't mean in the words and music sense).

Still, it shows that there are other voices to be heard. South Africa has exported musicals, both during and after the apartheid era. The first was called King Kong, and contrary to what you might think, neither Fay Wray nor the Empire State Building was involved. In fact, it was the story of a boxer, and the cast and creative team brought together both black and white artists. An all black team brought us Sarafina!, while a mixed-race team created Kat and the Kings, making sure that each of 
the country's splintered ethnic groups have been represented. Some of these works follow the Western conventions more than do others. After all, the Zulus have a centuries old tradition of narrating stories through song. I asked John Sparks how the craft of musical writing, as taught by Lehman Engel, might be adapted to suit this environment. "If... you are in a culture where the music and words are not part of the drama, but more of a decoration, more like scenery than content, then of course, that craft would not be so important."10

In Australia, the development of indigenous musicals was hampered by the fact that J.C. Williamson, the country's predominant impresario, had early on determined that Australians were not interested in hearing their own voices. This was a by-product of the post-Colonial "cringe factor" mindset which, like Canada's inferiority complex, is very hard to unseat. Australians have been writing musicals ever since Oscar Asche had an international hit with Chu Chin Chow in 1916, but it was several decades before any show emerged that felt Australian. An early attempt was an operetta called Collitts Inn by composer Varney Monk in 1932, which even attempted an aboriginal "corroboree." However, they had more success with developing performers than writers. Phillip Quast, Anthony Warlow, Caroline O'Connor and Hugh Jackman have all become international stars. In recent years, The Boy from $\mathrm{Oz}_{z}$ and Priscilla Queen of the Desert, both jukebox musicals, have enjoyed both domestic and international success. On the home front, they seem to have developed their own brand of cabaret musicals with the recent successes of Shane Warne: The Musical about a cricket legend, and Keating, about a former Labor Prime Minister.

My book will go into far more detail on these shows and others. I will look at how Japan has developed its own traditions with the all-female Takarazuka Revue and how Korea has been adapting its films into stage musicals. Even Argentina has produced at least one international musical star with Elena Roger.

Of course, the American musical has been a ubiquitous influence. John Sparks says, "The American musical does have impact in other cultures, first by being performed in translation, and ultimately by imitation. But as other cultures adopt and adapt the form, it changes and becomes suitable to the culture borrowing the style. This is how European operetta morphed into the American musical in the first place, being infused with jazz and variety, taking bits from African American music styles, from vaudeville and other influences that were at the time rather uniquely American."11

In many of the places I have studied, workshops and showcases have grown up to foster indigenous work. Here in Canada we have Script Lab. In Australia, the Pratt Prize is given out every 
two years for the best new Australian musical, and OzMade Musicals produces an annual showcase of new works in development. The Danish Musical Theatre Academy's "Uterus" program accepts work from both Danish and international writers. In Singapore, Musical Theatre Limited are trying to nurture musicals in a country where little tradition in the performing arts exists. In London, I am a member of Mercury Musical Developments, where they are struggling to encourage new work in spite of there being little financial support from either the government or the entertainment industry. I believe we would all benefit from some sort of network linking all these disparate activities.

Let's become as aware of the international community in musical theatre as we are in cinema and world music. Let's reclaim that middle ground by reaching out to a populist audience and then raising their aspirations (as Mozart did with The Magic Flute). That way, we can re-invigorate the musical. Who knows? We may even make it cool again.

\section{Notes}

1 "The Musical Comedy Book," Dramatists Guild Quarterly 25 no. 4 (Winter 1988): 8.

2 Cited in Peter Stone, Jerry Bock, Sheldon Harnick and Joseph Stein, "Landmark Symposium: Fiddler on the Roof", Dramatists Guild Quarterly, New York, 1983, Vol.20, No.1, p. 27

3 Alan Jay Lerner, The Musical Theatre: A Celebration (New York: McGraw-Hill Book Company, 1986), 236.

${ }^{4}$ Meryle Secrest, Leonard Bernstein - a Life (London: Bloomsbury, 1995), 52.

${ }^{5}$ John Warthen Struble, History of American Classical Music (New York: Checkmark Books / Facts on File, 1995$), 188$.

${ }^{6}$ Michael Coveney, "Oliver!: The real story of Britain's greatest musical”, The Independent (9 January 2009):

http://www.independent.co.uk/arts-entertainment/theatre-dance/features/oliver-the-real-story-of-britains-greatestmusical-1232964.html

7 John Coulter, "The Canadian Theatre and the Irish Exemplar," Theatre Arts Monthly (July 1936): 505-506.

8 John Sparks, personal communication.

${ }^{9}$ Wilfred Mellers, Music in a New Found Land: Themes and Developments in the History of American Music (London: Faber and Faber, 1987), 447.

10 John Sparks, personal communication.

11 Ibid.

\section{Works Cited}

Coulter, John. "The Canadian Theatre and the Irish Exemplar.” Theatre Arts Monthly (July 1936): 505506.

Coveney, Michael. “Oliver!: The Real Story of Britain’s Greatest Musical.” The Independent (9 January 2009): http:/ / www.independent.co.uk/arts-entertainment/theatre-dance/features/oliverthe-real-story-of-britains-greatest-musical-1232964.html

Lerner, Alan Jay. The Musical Theatre: A Celebration. New York: McGraw-Hill Book Company, 1986.

Mellers, Wilfred. Music in a New Found Land: Themes and Developments in the History of American Music. London: Faber and Faber, 1987.

Secrest, Meryle. Leonard Bernstein-A Life. London: Bloomsbury, 1995.

Stone, Peter, Jerry Bock, Sheldon Harnick, and Joseph Stein. "Landmark Symposium: Fiddler on the Roof.” Dramatists Guild Quarterly 20 no. 1 (1983): unpaginated. 
Struble, John Warthen. History of American Classical Music. New York: Checkmark Books/Facts on File, 1995.

“The Musical Comedy Book. Dramatists Guild Quarterly 25 no. 4 (Winter 1988): unpaginated. 